\title{
Aesthetic Consolation: A Possible Remedy for Solastalgia in James Bradley's Clade (2017)
}

\author{
Abeer Mohammed Raafat Khalaf ${ }^{1}$ \\ ${ }^{1}$ Lecturer in English Literature, English Department, Faculty of Arts, Assiut University, Egypt \\ Correspondence: Abeer Mohammed Raafat Khalaf, Lecturer in English Literature, English Department, Faculty \\ of Arts, Assiut University, Egypt. E-mail: abeerkhalaf@aun.edu.eg
}

Received: June 9, 2020 Accepted: July 13, 2020 Online Published: July 16, 2020

doi:10.5539/ells.v10n3p54 URL: https://doi.org/10.5539/ells.v10n3p54

\begin{abstract}
Climate change is one of the significant and threatening problems worldwide. It has attracted the attention of scientists and politicians as well as writers and critics especially in the western world. Writers have responded by writing climate change fiction despite the challenges of representation. James Bradley, an Australian novelist and critic, is one of those writers who are deeply occupied by the impacts of climate change. He has written Clade (2017) which traces the life of Adam Leith, a climatologist, and his family descendants amid the disastrous consequences of climate change. To analyze this novel, the researcher focuses on solastalgia, and applies the approach of everyday aesthetics. In a nutshell, the paper attempts to highlight the impact of climate change, examine the relationship between the characters and their environment, and explore the possibility of adaptation and detection of aesthetic values in an environment destroyed by climate change.
\end{abstract}

Keywords: climate change, Cli-fi, everyday aesthetics, solastalgia, aesthetic consolation

“Climate Change is now. It's happening all around us." (Amitav Ghosh, 2017)

\section{Introduction}

Climate change is an existential problem, and ever since Greta Thunberg, a Swedish climate activist girl, started her strike in front of school to fight climate change, it has been given reconsideration and worldwide attention. She has encouraged 4 million people to participate in global climate strike on September 20, 2019 (Alter, Haynes, \& Worland, 2019). She delivers a speech in U.N.'s Climate Action Summit in New York City on September 23, 2019:

You have stolen my dreams and my childhood with your empty words. ... People are suffering. People are dying. Entire ecosystems are collapsing. We are in the beginning of a mass extinction, and all you can talk about is money and fairy tales of eternal economic growth. How dare you!

She is frustrated because governments and business companies are not reducing carbon emissions that cause climate change. Climate change is not a recent problem; thirty years ago heat-trapping emissions were observed as a result of burning fossil fuels and rain forests, so the Intergovernmental Panel on Climate Change was established in late 1988 after witnessing the impact of greenhouse gases (Revkin, 2018). But what is climate change? Or is it global warming? Generally, climate change and global warming are used interchangeably, but climate change points to the everlasting changes in climate such as sea level rise, extreme weather, and ocean acidification while global warming points to the marked increase of planet temperature as a result of greenhouse gas emissions (Romm, 2018). Climate change , according to Stephen Jackson (2018), is "periodic modification of Earth's climate brought about as a result of changes in the atmosphere as well as interactions between the atmosphere and various other geologic, chemical, biological, and geographic factors within the Earth system". The severe impacts of climate change are seen everywhere; so if strict actions are not applied, we are going to suffer from much more dangerous climate impacts (Romm, 2018). We, humans, are the cause of global warming, substantial pollution, species extinction and biodiversity loss, poisonous methane emission, melting icebergs, floods, draughts, wildfires, and forest damage (Jordan, 2014). Thus, climate change engaged scientists and politicians as well as writers and critics especially in the western world. Writers have responded by writing climate change fiction despite challenges of representation.

Climate change fiction or Cli-Fi is a term coined by the journalist Dan Bloom; he defines it in an interview as "a 
new genre term for novels, short stories and movies that stands for works of art and storytelling that deal with climate change and global warming (Thorpe, 2017). Since climate change fiction belongs to the field of ecocriticism (Trexler \& Johns - Putra, 2011), ecocriticism should be explained. In 1996, Cheryll Glotfelty defines ecocriticism as "the study of the relationship between literature and the physical environment" (p. 18). He writes the term was first introduced in 1978 by William Rueckert in his work "Literature and Ecology: An Experiment in Ecocriticism". Similarly, Sandip Mishra (2016) explains ecocriticism to be "an earth centric approach to literary studies which promotes the understanding of who we are, where we stand, how we should behave with our mother nature etc." (p. 169). In addition, ecocriticism has focused on two things: dedicating itself to defending and taking care of the natural world, and establishing a relationship between the human and non-human world. It also raises human's awareness of the environmental problems which are a result of man's abuse (p. 168). Furthermore, Camilo Gomides (2006) demonstrates the field of ecocriticism addresses works of literature focusing on the moral aspect of human beings' interaction with nature besides showing readers what could take place in the future. There are two ecocritical approaches to climate change literature: the first approach is to envision how to cope with climate change, and the second one is to understand the nature of climate change as a cultural phenomenon (Johns - Putra, 2016). Thus, the function of climate change fiction is to reevaluate some of the motifs, themes, and ideas presented in the field of ecocriticism (Mehnert, 2016).

Climate change fiction has gradually spread all over the world; many novels from Germany, Norway, Iceland, Spain, Finland, and Netherlands have been translated into English (Trexler, 2015). Novelists have represented climate change not just as a setting for their work, but they also depict the psychological, sociological, and ecological impacts (Trexler \& Johns - Putra, 2011). Climate change fiction is literature that predicts the future by showing the destruction taking place, and presents two scenarios: the first represents the degradation of social, economic, and ecological life while the second one represents the ability to cope and adapt to the new environment (Crownshaw, 2017). Noticeably, in most cases, it attempts to show the destructive impact of climate change on human beings. The setting of these narratives could be in the past, present, or future in threatened environments. As for the technique and point of view employed, they vary from one narrative to another but with a focus on the scientific point of view. The climax is depicted as a huge change in the setting such as floods or food system collapse which makes the plot unfold quickly (Irr, 2017). The purpose of climate change fiction is to make readers understand the influence of climate change on people and societies which occurs by providing scientific facts to enrich the understanding of the future. "Climate fiction can make the not yet real become believable" (Beach, Share, \& Webb, 2017, p. 64). Climate change fiction, as Antonia Mehnert (2016) analyzes, has to refer to the anthropogenic aspect of global warming as it depicts human beings complicated relationship with earth. Moreover, it addresses the role of human beings in dealing with this uncommon disaster. In a nutshell, she provides a comprehensive view of climate change fiction:

Climate change fiction - literature dealing explicitly with anthropogenic climate change — gives insight into the ethical and social ramifications of this unparalleled environmental crisis, reflects on current political conditions that impede action on climate change, explores how risk materializes and affects society, and finally plays an active part in shaping our conception of climate change. It thus serves as a culturalpolitical attempt and innovative alternation of communicating climate change. (p. 4)

Climate change fiction has been applauded because it not only entertains but educates at the same time; it realistically portrays the future based on scientific facts (Evans, 2017). In fact, depicting climate change, as Kathryn Yusoff and Jennifer Gabrys (2011) indicate, is an innovative process involving the overlap of three fields: sciences, social sciences, and humanities.

\section{Climate Change: Slow Violence}

Climate change is considered to be slow violence according to Rob Nixon (2011). Slow violence means "a violence that occurs gradually and out of sight, a violence of delayed destruction that is dispersed across time and space, an attritional violence that is typically not viewed as evidence at all" (p. 2). Human and environmental loss are neither noticed or counted; "Causalities of slow violence become light—weight, disposable casualties, with dire consequences for the ways wars are remembered" (p. 13). This means people do not witness the direct severe impact of climate change on their daily lives. Likewise, Axel Goodbody (2014) pinpoints the nature of climate change is abstract; thus, people do not feel its danger even though they exist in countries that support the protection of the environment. They are alerted by "unusually hot summers, mild winters, early springs, draught, and extreme weather occurrences such as hurricanes" (p. 2), but they do not see the connection between it and global warming. Nixon (2011) believes writer activists have the means to convey the invisible slow violence of climate change, and make us understand, see, and feel the disaster: "In a world permeated by insidious, yet unseen or imperceptible violence, imaginative writing can help make the unapparent appear, making it accessible 
and tangible by humanizing drawn-out threats inaccessible to the immediate senses" (p. 15).

James Bradley, an Australian novelist and critic, is one of those writers who has responded to the climate change issue. He wrote Clade (2017) which depicts the life of Adam Leith, a climatologist, and his family and friends, from the present to the future, stuck in a world hit by climate change where earth suffers from rising sea levels, floods, fires, droughts, extinction of species, and pandemics. Clade "is the scientific term for a group of organisms with a common ancestor, and comes from the Greek word klados, or branch" (Bradley, 2017c). Adam is considered the common ancestor, and the group of organisms is his family and friends. The structure of the novel is similar to a honeycomb; it consists of ten concise, compact chapters narrated by multiple points of view. Clade confirms Nixon's idea of slow violence which is expressed in the beginning when one of Adam's colleagues summarizes the core of climate change problem: "We don't change because we don't believe in the problem,' he would say, "at least not at the deep, intuitive level we need to. We can see it when it's in front of us, see what it means; we know we have to change. But as soon as we're away from it our old thinking reasserts itself, our desire to reproduce, to build power" (Bradley, 2017a, p. 19).

Bradley vividly depicts the impacts of climate change in the present and future. He describes the flood that sweeps England when Adam is visiting his daughter, Summer:

At first all that is visible is the rising water, the refuse floating by. But then he hears a rushing noise, accompanied by creaking and grinding like wind. And then, at the street's end, he sees it. It seems so improbable it's difficult to be afraid, for it is as if the water is pouring towards them in a sloping wall, a liquid hill that moves faster than any of them could run, a wave that does not end but comes and comes and comes. (2017 a, p. 83)

Bradley also refers to the bee colony collapse disorder through the dialogue between Amir, a doctor from Dhaka and beekeeper, and Ellie, Adam's ex-wife. Amir expresses his fear: "None of the collapses before have been anything like this. It began in Europe but spread through America and Asia in less than a year. For a while we were protected, but now the colonies here are dying as well" (2017a, p. 105). In addition, Bradley sheds light on the displacement of populations problem. Amir's presence in Australia is illegal; the government in Bangladesh collapsed, so he and his family are sent to camps, but he runs away after the death of his wife and daughter. He narrates his story to Ellie, "I was in the camps for a long time. One day I escaped. I didn't know where to go. I was hurt in my heart, depressed, almost catatonic" (2017a, p. 106). Then, Bradley moves on to portray a pandemic starting in China caused by a virus called Acute Viral Respiratory Syndrome, or AVRS: "The media ban is still in place in China but the images that are getting out are bad: hospitals overflowing, bodies in the streets. It's the same all over Asia, and in America and Europe" (2017a, p. 145). Furthermore, many species are extinct: "These are the things we've lost: Birds/Bananas/Tigers/Frogs/Bees/Coffee/Polar bears/Coral. These are the things we've saved: Seeds/Elephants/Dolphins/Each other" (Bradley, 2017a, p. 148). The disastrous consequences of climate change are realistically portrayed, and as climate change attacks one's surroundings, 'place' becomes significant.

\section{Significance of 'Place'}

Place is of great concern to human beings. Arto Haapala (2005) explains the concept of 'place' through the approach of everyday aesthetics: "The concepts of place and everyday are further linked to the idea of familiarity. Place and the everyday objects and events that constitute a place are marked by familiarity" (p. 40). He adds place depends on the presence of physical location in addition to stability; for example, trees, houses, pens, etc. all have a place somewhere. There is also the expression 'sense of place' which refers to an animal or a person who can feel, see, and understand things related to a place. Besides the 'sense of place,' there is the 'spirit of place' which focuses mainly on the 'nature of a place' more than on the person who feels it. Thus, a place does not always refer to the cultural background though it does most of the time. A place has both a sense and a spirit. For instance, when someone asks what forms the spirit of a town or a city, the answer would hint to the cultural background. If one goes to Paris, he/she could detect the French and Parisian influence on both the architecture and people's customs. People growing up in Paris will reflect the spirit of the place because it is part of their nature, and when a stranger visits the place, he/she notices its magnificence since it is not like his/her background. The stranger is able to see the differences from a distance because they do not form his/her identity like those living there. Adam notices the differences and the consequences of climate change in England since his last visit which was ten years ago: "Yet the weather is less striking than the changes to the city in the decade since he was last there- the closed shops, the beggars sleeping on footpaths, the cracks in the asphalt, the groups of young people congregated on corners. The police vans with blackened windows parked every block or two" (Bradley, 2017a, p. 66). Since England does not shape his identity, and is not familiar to him, he immediately 
realizes the strangeness.

Place, according to Haapala (2005), holds its significance when connection is established between daily life and people's surroundings, and this connection causes familiarity; so if the familiar surroundings change, people begin to recognize the differences. Ellie is not so comfortable with the change of her familiar surroundings:

When she lived in the city, she would often spend the evenings sitting on the front steps and staring into the night, listening to the sound of the traffic and thrilling to the sense of a secret world unfolding in the sleeping streets. Out here the night is quieter, the sounds - those of shrieking possums and feral cats or the distant barking of dogs - are stranger, less easy, yet the sensation that time is expanding, that a different way of being lies just beneath the skin of the moment, is no less strong. (Bradley, 2017a, p. 110)

She misses Sydney, which represents her familiar surroundings. Based on Haapala's (2005) work, Ariane Nomikos (2018) claims, "Places have significant affective and aesthetic dimensions that directly impact mental health and subjective well-being" (p. 453), and that "one way to think about the aesthetic character of places is in terms of strangeness and familiarity" (p. 456). Haapala (2005) defines strangeness as things or events which are uncommon to a person present in a new environment, and it is the feeling you receive due to the fresh encounter in this new environment. When one comes into contact with new surroundings, he/she is alert to everything around him; he/she notices the details even if they are insignificant. "In one sense of the word aesthetic, strangeness creates a suitable setting for aesthetic considerations" (p. 44). A person's senses could detect the differences between one's background and the new one. Consequently, he/she could objectively evaluate the new place without bias because it has not yet become part and parcel of this person. However, strangeness does not continue to exist since a person will have to form ties with this new environment. When a person lives in a place, he becomes attached to it as if this place is part of him/her. People have different interests in the environment in which they live; these interests have been developed throughout their lives. Therefore, place becomes distinctive as bonds have been established between people and that place. People function in the environment which has become their home. Furthermore, "Placing' is the process of 'home building.' Familiarizing oneself with the environment is home building in the sense that home is by definition of utmost familiarity. Home is a place where everything is familiar. Home is something where most of the matters are under control." Unfortunately, strangeness destroys this 'home building' sense and the need for familiarity to hold on and go on in life (Haapala, 2005, p. 46). In brief, familiarity leads to place attachment (Nomikos, 2018) which is an emotional relation formed between people and the place (Haapala, 2005). So, when peoples' familiar surroundings are threatened, they are unable to find comfort in their everyday life (Nomikos, 2018).

\section{Solastalgia}

Climate change not only attacks the familiarity of a place but also causes psychological pain which is referred to as solastalgia by Glenn Albrecht (2005), an environmental philosopher at the University of Newcastle. He theorizes:

'Solastalgia' was created to describe the specific form of melancholia connected to lack of solace and intense desolation. Solastalgia has its origins in the concepts of 'solace' and 'desolation'. Solace is derived from solari and solacium, with meanings connected to the alleviation of distress or to the provision of comfort or consolation in the face of distressing events. Desolation has its origins in solus and desolare with meanings connected to abandonment and loneliness. As indicated above, algia means pain, suffering or sickness. (pp. 44-45)

He indicates the term is similar to nostalgia with emphasis on the role of place. In other words, solastalgia exists when one suffers from pain or feels sick due to the absence of comfort and the feeling of desolation in relation to the prevailing conditions of "one's home and territory" (p. 45). He mentions the conditions for the existence of solastalgia: first, it is the pain felt when the place one is connected to is directly attacked, and he calls it "physical desolation'. Adam is in pain due the impact of climate change not just on his country but on the whole world. At first, he refused to give up to

despair over the changing climate ... But as the situation grew ever more urgent he found himself increasingly alarmed about what was to come. ...In the Arctic the permafrost was melting; in Greenland and Antarctica the ice sheets were destabilizing, their deterioration outpacing even the most pessimistic models. (Bradley, 2017a, p. 18)

He is aware of the impact of place upon him and his colleagues as one of them wrote, "the emptier the land, the more luminous and precise the names for its features ... it captures his feeling he is in a place of the infinite, a place that exists without reference to the human" (Bradley, 2017a, p. 20). 
The second condition of solastalgia occurs when one's sense of place is lost and is depressed due to the inflicting changes upon that place, and he calls it 'psychological desolation' (Albrecht, 2005). Adam is psychologically disturbed, and this appears when he criticizes the role of media's coverage of climate change, and accuses them of being irresponsible: "They're like cancer" (Bradley, 2017a, p. 28). He is frustrated, but Ellie replies, "Sometimes it's like you actually want the worst to happen because it will mean you're right, and the world is fucked" (Bradley, 2017a, p. 29). Albrecht (2005) explains solastalgia can happen when place identity is influenced by current changes to the supposed to be stable system. Also, Ellie is psychologically unstable as she is worried about the impact of climate change: "I'm interested in the different ways we perceive and represent plants and animals, the way encountering those representations can sometimes be like glimpsing a lost world, all of its own. ...Doesn't it frighten you" (Bradley, 2017a, pp. 12-13)?

The third condition exists if one's passionate request that the place where he/she belongs would always provide peace is not met. Solastalgia does not mean digging into the past or searching for another place to call home; it is the feeling of loss and the inability to find solace in the present (Albrecht, 2005). Ellie works on a project about Alzheimer's; she is distracting herself by depicting the faces of these patients and their loss of memory and speech: she is "so absorbed in a project which is about the loss of the self, the annihilation of memory, suggesting as it does some desire to escape the present" (Bradley, 2017a, pp. 30-31). Ellie is depressed; she is solastalgic. Albrecht (2005) suggests solastalgia "may seek its alleviation in a future that has to be designed and created" (p. 45). Many years later, Ellie moves into a new house near a valley where she finds an old hive and plans to study bees and photograph them. She is creating a virtual world of bees similar to the real one as an attempt to find solace:

With a stab of sadness, she realizes she was right about the project's strength ... Likewise the close-ups of their faces- the blankness their eyes reveal when expanded both invite and repel identification; their unknowability is like a space into which one can fall, a reminder of the presence of otherness in the world, and of the loss of its passing. (Bradley, 2017a, p. 117)

There are factors that contribute to the feeling of solastalgia "which can be both natural and artificial. Drought, fire and flood can cause solastalgia, as can war, terrorism, land clearing, mining, rapid institutional change and the gentrification of older parts of cities" (Albrecht, 2005, pp. 45-46). Ellie's depression worsens after her daughter's disappearance and the discovery of a grandchild: "It didn't help that the world seemed to be falling apart as well, the floods in England followed by deluges in northern Europe and Burma, the escalation of the war in the Middle East and the horrors in Chicago" (Bradley, 2017a, p. 98). She is influenced by both natural and artificial factors of solastalgia.

Summer, Adam and Ellie's daughter, is also distressed. She has left Australia and lives in England with her son, Noah. In a conversation with Adam, she appears to be disappointed and angry about the impact of climate change. When Adam asks her if they have lost much in the flood, she replies, "Stuff? Some. But people died, Dad. A lot of them. Or had you forgotten that" (Bradley, 2017a, p. 71)? Moreover, Noah suffers from autism, and is always worried about the weather; Summer says, "But all this stuff, with the water and the flood and the storm, it stresses him, makes him worse. He gets incredibly wound-up, can't stop talking about it" (Bradley, 2017a, pp. 73-74). Unfortunately, a storm hits England during Adam's visit. Bradley gives a vivid description of the storm:

Even after a lifetime in Sydney Adam finds the sheer volume of water startling, the way they are drenched almost immediately. Yet it isn't the rain that is truly frightening but the wind, which strikes like a living thing, bending trees back upon themselves and flinging branches and bins and scraps of clothing through the air. In Adam's arms Noah makes a low, keening noise, clinging to him like an animal. (2017a, p. 78)

Adam, Summer, and Noah are exposed to horrible images after the flood: "More than once they come across bodies caught in the wreckage. A man pinned to a wall by a car, a woman faces down in a sump, a girl hanging suspended in the branches of an overturned tree. At first, they try to shield Noah's eyes, but after the third body they give up" (Bradley, 2017a, p. 89). Adam's family suffers from solastalgia, and this is emphasized by Bradley's reply in an interview with Amy Brady, "Certainly, I wanted to capture something of the sense of grief associated with the loss of places and species and human possibility" (Bradley, 2017b). Despite the grief, Bradley presents aesthetic consolation as a means to cope with the transformations of climate change.

\section{Aesthetic Consolation}

The consequences of climate change are severe, and in addition to attacking infrastructures, it attacks whatever is important for people (Nomikos, 2018). Bradley depicts this point: 
The rains that usually arrived in July or August failed to appear, leaving the subcontinent to bake in record heat. Crops failed, leading to food shortages and starvation. Then in November torrential rain and massive floods killed more than a million and left another hundred million homeless. And finally, in the aftermath, the economy collapsed, leading to the widespread unemployment that is behind the riots in Mumbai and Calcutta in recent weeks. (2017a, p. 25)

Nomikos (2018) proposes the idea of everyday aesthetic consolation to reduce the loss caused by climate change: "The familiar everyday aesthetic character of our surroundings can help combat the stressors of daily life that threaten ontological security" (p. 459). She argues the sense of familiarity of everyday disappears due to changes in the environment, and this threatens the ontological security which may cause anxiety, stress, and isolation. Unfortunately, the familiar places no longer present comfort and stability besides being a constant reminder of the disasters that took place. The aesthetic character of everyday life extends not only to cover the aesthetic character of the place that maintains the continuity of everyday life but also to creating familiarity to stand up against desolation and insecurity. Familiarity can be detected in the daily activities performed, and the most important is the 'ongoing' of these activities to enhance one's well-being. The familiarity of routine could counteract the feelings of displacement resulting from changes to the aesthetic character of one's familiar environment. Performing everyday aesthetic activities that maintain the routine system of everyday life can achieve stability amid the horrendous changes. Bradley shows how Noah sees beauty by playing in the garden every day and using his telescope to watch the stars: "They seemed so perfect, so still, their beauty disguising their unimaginable violence ... It was possible to be afraid of that but he was not; instead it seemed wondrous such violence could create such beauty" (2017a, p. 209). To find solace in the current state, one has to resort to what he/she can control to adapt to the changes.

Climate change causes strangeness in everyday life which people notice by focusing on its aesthetic character, and this creates a sense of discomfort. However, life will go on despite the drastic changes, and people will perform their daily routine and activities. Of course, it is going to be extremely hard to ignore the strangeness and the instability, but it is conceivable. Fortunately, there is a way to come to terms with this strangeness by trying to accept the unconventional features intruding on the environment. If this is achieved, people may adapt to the new environment, and the sense of appreciating the aesthetics of the unfamiliar is enhanced (Nomikos, 2018). Bradley sheds light on aesthetic values in the environment despite the disastrous changes caused by climate change; for example, when Maddie, Ellie's step-mother, sees beauty in the beach though "the rising water has carried off more and more of the beach ... she has come to feel there is something beautiful in the ruination of the beach" (Bradley, 2017a, p. 34). Also, after the storm that tears England apart, Summer refers to the beauty of the stars saying, "They're so bright," and Adam confirms, "With the power down, there are no lights to interfere with them" (Bradley, 2017a, p. 86). In addition, he "is stuck by the beauty of the planet's transformation, the indifferent majesty of the change that is taking place" (Bradley, 2017a, p. 88). Many years later, Noah stands in the desert realizing that land is in constant change, and that when he first came to the place, he was afraid, "but as the years have passed he has learned to appreciate the echoes of other ages contained within it, to love the frozen archaeology of the broken rock, the lifted plains, the dust" (Bradley, 2017a, p. 210). At the end of the novel, Bradley portrays a scene where Izzie, Lijuan's daughter, lies on the beach watching the Shimmer, flickering dance of lights. The cause of this phenomenon is not known:

The best guess of most scientists is that they're related to a new instability in the earth's magnetic fields ... But there also those who believe the process has been hastened by the events of the last century, claiming that the incremental changes to the Earth's rotation caused by the melting of the ice and the shifting of the crust as it adapted to its loss have destabilised the fields in new and unpredictable ways. (2017a, p. 221)

Climate change will not change the familiar into strangeness at once. Thus, the aesthetic character will be slightly influenced. Strangeness might be detected before noticing what actually caused it, and this process leads to aesthetic investigation. This strangeness makes people recognize the characteristics of their environment as they look for the nonaesthetic elements that changed the aesthetic character of their environment. As people start looking, they stimulate their minds to remember what their environment used to look like. This process would demonstrate the changes that have taken place and aid in establishing a strong positive place attachment (Nomikos, 2018). Bradley tries to reduce the feeling of desolation by presenting the idea of simulation as a way to deal with the strangeness in the environment. Li Lijuan, the daughter of Noah's nurse, calls a simulation of life before the change: "The noise was incredible. Birds shrieking and singing, things moving in the undergrowth. Even the light was different, thicker somehow, full of smoke and colour. It was so amazing" (2017a, p. 146). Also, Bradley introduces "sims or echoes. Virtural recreations of the dead assembled from photos and videos ... At their core is a cloned, virtual Artificial Intelligence, programmed with heuristics that allow it to read the 
responses of people it interacts with" (2017a, p. 163) as an attempt to show how people will cope with the impact of climate change. Nomikos (2018) mentions it is acceptable to find comfort and aesthetically value the familiarity of everyday routine and at the same time denounce the new strangeness and cherish the idea that made us aware of the aesthetic character of our environment. However, this does not mean we find pleasure in its continuity. To put it clearly, to be able to lead a life full of meaning, one should concentrate and find value in what can be controlled, not what is beyond one's control.

\section{Conclusion}

Climate change is not a recent problem; its repercussions are present since the Industrial Revolution. To convey climate change and its consequences is not an easy matter because of its elusive nature; its immediate consequences are not clearly witnessed. However, writers continue to write climate change fiction which succeeds in informing readers about climate change and its disastrous impacts. But it is not the mission of all climate change fiction just to depict the horrible consequences of climate change because if this was the case then what is the creative role of fiction? It should alert the audience to the problem. The best story should show us how the protagonist lives and deals with different issues as the world collapses (Yusoff \& Gabrys, 2011). Clade achieves this effect; it engages with the challenges of time, place, and human agency that climate change presents. Bradley portrays the characters' intricate relationship with the environment; he connects the present and the future showing the transformation in the environment. Adam's family suffers from solastalgia as they face physical and geological challenges. Their sense of place is lost, and they are grieving, but they manage to adapt to some extent by resorting to aesthetic consolation. They come to terms with the strangeness and detect aesthetic value in their surroundings. Beauty will continue to exist whatever the circumstances. Clade is not an apocalyptic story but a cautionary one; Bradley delivers an optimistic message through one of his characters: "And she realizes that whatever else happens, this is not an end but a beginning. It is always a beginning" (2017a, p. 222). Life will go on and hope is to be the remaining option for humanity in this chaotic world.

\section{References}

Albrecht, G. (2005). 'Solastalgia'. A new concept in health and identity. PAN: Philosophy Activism Nature, 3, 41.

Alter, C., Haynes, S., \& Worland, J. (2019). TIME 2019 Person of the Year: Greta Thunberg. TIME. Retrieved from https://time.com/person-of-the-year-2019-greta-thunberg/

Beach, R., Share, J., \& Webb, A. (2017). Teaching climate change to adolescents: Reading, writing, and making a difference. Routledge. https://doi.org/10.4324/9781315276304

Bradley, J. (2017a). Clade [PDF file]: Titan Books (US, CA). Retrieved October 8, 2019 from https://b-ok.africa/book/4515010/8e 72dd

Bradley, J. (2017b). How Will Climate Change Affect Your Grandchildren? (A. Brady (Ed.).

Bradley, J. (2017c). Interview with James Bradley, author of Clade (T. Qwillery Ed.).

Crownshaw, R. (2017). Climate Change Fiction and the Future of Memory: Speculating on Nathaniel Rich's Odds against Tomorrow. Resilience: A Journal of the Environmental Humanities, 4(2-3), 127-146. https://doi.org/10.5250/resilience.4.2-3.0127

Evans, R. (2017). Fantastic Futures? Cli-fi, Climate Justice, and Queer Futurity. Resilience: A Journal of the Environmental Humanities, 4(2-3), 94-110. https://doi.org/10.5250/resilience.4.2-3.0094

Glotfelty, C., \& Fromm, H. (1996). The ecocriticism reader: Landmarks in literary ecology. University of Georgia Press.

Gomides, C. (2006). Putting a New Definition of Ecocriticism to the Test: The Case of "The Burning Season", a Film (Mal) Adaptation. Interdisciplinary Studies in Literature and Environment, 13-23. https://doi.org/10.1093/isle/13.1.13

Goodbody, A. (2014). Risk, denial and narrative form in climate change fiction: Barbara Kingsolver's Flight Behavior and Ilija Trojanow's Melting Ice. The Anticipation of Catastrophe: Environmental Risk in North American Literature and Culture, 39-58.

Gosh, A. (2017). Where's the Great "Climate Change Novel"? A Conversation with Amitav Ghosh (S. Paulson Ed.).

Haapala, A. (2005). On the aesthetics of the everyday: familiarity, strangeness, and the meaning of place. The Aesthetics of Everyday Life, 39-55. 
Irr, C. (2017). Climate fiction in English Oxford Research Encyclopedia of Literature. https://doi.org/10.1093/acrefore/9780190201098.013.4

Jackson, S. T. (2018). Climate Change. Retrieved April 16, 2020, from https://www.britannica.com/science/climate-change

Johns - Putra, A. (2016). Climate change in literature and literary studies: From cli - fi, climate change theater and ecopoetry to ecocriticism and climate change criticism. Wiley Interdisciplinary Reviews: Climate Change, 7(2), 266-282. https://doi.org/10.1002/wcc.385

Jordan, D. (2014). Climate change narratives in Australian fiction. Lambert Academic Publishing.

Mehnert, A. (2016). Climate Change Fictions: Representations of Global Warming in American Literature. Springer. https://doi.org/10.1007/978-3-319-40337-3

Mishra, S. K. (2016). Ecocriticism: A study of environmental issues in literature. BRICS Journal of Educational Research, 6(4), 168-170.

Nixon, R. (2011). Slow Violence and the Environmentalism of the Poor. Harvard University Press. https://doi.org/10.4159/harvard.9780674061194

Nomikos, A. (2018). Place matters. The Journal of Aesthetics and Art Criticism, 76(4), 453-462. https://doi.org/10.1111/jaac. 12598

Revkin, A. (2018). Climate Change First Became News 30 Years Ago. Why Haven't We Fixed It? Retrieved April 14, 2020, from https://www.nationalgeographic.com/magazine/2018/07/embark-essay-climate-change-pollution-revkin/

Romm, J. (2018). Climate Change: What Everyone Needs to Know®. Oxford University Press.

Thorpe, D. (2017). Dan Bloom on CliFi and Imagining the Cities of the Future (D. Bloom Ed.).

Trexler, A. (2015). Anthropocene fictions: the novel in a time of climate change. University of Virginia Press.

Trexler, A., \& Johns - Putra, A. (2011). Climate change in literature and literary criticism. Wiley Interdisciplinary Reviews: Climate Change, 2(2), 185-200. https://doi.org/10.1002/wcc.105

Yusoff, K., \& Gabrys, J. (2011). Climate change and the imagination. Wiley Interdisciplinary Reviews: Climate Change, 2(4), 516-534. https://doi.org/10.1002/wcc.117

\section{Copyrights}

Copyright for this article is retained by the author, with first publication rights granted to the journal.

This is an open-access article distributed under the terms and conditions of the Creative Commons Attribution license (http://creativecommons.org/licenses/by/4.0/). 